\title{
Pengaruh Kecerdasan Emosional Terhadap Budaya Kerja di PT Asuransi Bumiputera Muda 1967 Cabang Pekanbaru, Dumai dan Padang
}

\author{
PRAMA WIDAYAT \\ Dosen Tetap Universitas Lancang Kuning \\ Jln. Yos Sudarso Km 08 Rumbai Pekanbaru Telp. (0761) 52581 \\ E-mail : pramawidayat@unilak.ac.id
}

\begin{abstract}
This study aims to see the effect of emotional intelligence on work culture in PT Asuransi Bumiputera Muda 1967 Branch Pekanbaru and Dumai. This study uses descriptive method by conducting investigations and interviews directly with some employees and marketing personnel called partners. The results showed that there is a positive effect of emotional intelligence with employee work culture but its influence is not significant. This indicates that a person who has maturity from the emotional side will be able to control themselves in daily work, both to fellow employees and customers. Emotional intelligence is needed to maintain an atmosphere of harmonious inter-individual relationships so that the organization will be embedded culture of mutual help, speak the language of polite, tidiness in work, loyalty to the company and a good work ethic.
\end{abstract}

Keywords: emotional intelligence and work culture

PT. Asuransi Umum Bumiputera Muda 1967 (Bumida) merupakan tempat penulis bekerja dari tahun 2010-2014 Sehingga mengetahui segala permasalahan yang terjadi secara internal dan mengenal baik personal yang ada diberbagai cabang terutama di Pekanbaru dan Dumai. Bumida merupakan perusahaan yang bergerak dibidang Asuransi Umum dengan memiliki cabang diseluruh Indonesia dan tentunya berbagai etnis yang tergabung didalamnya. Sehingga otomatis terjadi pertukaran budaya didalamnya tak dipungkiri konflikkonflik antar personil sering terjadi karena latar belakang budaya yang berbeda tersebut, jika tidak dikelola dengan baik maka akan menimbulkan persaingan yang tidak sehat dan pada akhirnya melemahkan perusahaan dalam persaingan dunia asuransi.

Semakin ketatnya persaingan bisnis di bidang asuransi terutama dalam memberikan jasa pelayanan yang paripurna, karena pada hakekatnya jasa adalah bagaimana memberikan pelayanan yang excellent kepada pelanggan dengan meningkatkan performance manajemen secara internal, mulai dari kedisiplinan waktu bekerja, tidak membedakan antara nasabah besar dan nasabah kecil, kecepatan dan ketepatan dalam bekerja, menjaga sikap dan prilaku selama bekerja serta yang terpenting adalah bagaimana menjaga perasaan dan mampu memahami apa yang dibutuhkan customer. Seperti hal nya yang disampaikan oleh Ivancevic (2006) bahwa budaya organisasi merupakan merupakan apa yang dipersepsikan oleh karyawan dan cara persepsi itu menciptakan suatu pola keyakinan, nilai dan ekspektasi. Begitu banyaknya perusahaan asuransi yang ada di Indonesia saat ini maka setiap perusahaan harus menciptakan kekuatan secara internal terlebih dahulu agar mereka mampu bersaing secara seivanhat. Salah satu hal yang bisa dilakukan dengan menciptakan budaya kerja yang kondusif dan profesional karena hal inilah yang akan nantinya dijadikan acuan dan standar dalam bekerja dalam melayani konsumen, budaya ini disepakati secara bersama untuk mendukung tujuan perusahaan jangka pendek dan jangka panjang. 
PT. Asuransi Umum Bumiputera Muda 1967 (Bumida) juga tidak terlepas dari berbagai problematika dan dinamika didalam organisasi karena individuindividu yang bekerja memiliki tingkatan kematangan emosional yang berbeda antara yang satu dengan lainnya. Terlepas mereka telah atau belum mengikuti pelatihan ESQ yang diselenggarakan oleh lembagalembaga profesional. Banyaknya karyawan yang keluar masuk dan perampingan organisasi merupakan hal yang tidak bisa dihindari oleh Bumida sesuai dengan budaya perusahaan tersebut.

Sebagai manusia kita tidak luput dari permasalahan, namun yang terpenting adalah bagaimana kita mengendalikan diri baik secara emosional maupun spiritual agar permasalahan tersebut bisa disalurkan menjadi energi positif. Itulah beberapa problema yang terjadi. Peneliti memfokuskan penelitian pada PT. Asuransi Umum Bumiputera Muda 1967 cabang Pekanbaru, Kota Dumai dan Kota Padang sesuai daerah terdekat dengan domisili peneliti. Perusahaan ini berdiri tahun 1967 dan sekarang memiliki 44 cabang Konvensional dan 3 cabang Syariah di seluruh Indonesia. Tetapi peneliti hanya memfokuskan di Cabang Pekanbaru, Kota Dumai dan Kota Padang dengan jumlah karyawan dalam dan lapangan lebih kurang 60 Orang.

Kecerdasan Emosional. Untuk mengukur Emotional Question terdapat 5 (lima) pendekatan yang dilakukan menurut Tikollah (2006).

1. Mengenali diri sendiri, mampu mengenali kekurangan dan kelemahan secara pribadi

2. Mengelola emosi, mampu mengendalikan emosi dalam kondisi normal maupun dalam kondisi tertekan, atau dengan kata lain mampu mengelola emosi secara cerdas.

3. Memotivasi diri sendiri, tidak takut akan tantangan pekerjaan yang akan dihadapi bahkan

mampu memberikan sumbangan ide atau pemikiran.

4. Mengenali emosi orang lain, mampu menempatkan posisi disaat orang lain membutuhan kita untuk memberikan masukan ataupu ide serta mampu mengintrospeksi diri sendiri

5. Membina hubungan, dalam berkomukasi baik secara verbal maupun non verbal tetap menjaga sopan santun dan etika dengan orang lain.

Bradberry (2007) menjelaskan bahwa Kecerdasan emosional adalah dua produk dari dua skill utama : kompetensi personal dan kompetensi sosial. Kompetensi personal lebih berfokus pada diri sendiri sebagai seorang individu dan terbagi kedalam skill kesadaran diri dan menejemen diri. Kompetensi sosial lebih berfokus pada bagaimana hubungan seseorang dengan orang lain dan terbagi kedalam skill kesadaran sosial dan skill manajemen hubungan sosial. Dari

Dari berbagai pendapat ahli diatas dapat disimpulakan bahwa EQ adalah kemampuan seorang individu untuk memahami diri sendiri dan orang lain, dan kemampuan untuk membina hubungan dengan khalayak banyak.

Mengenali Keadaan-keadaan Emosi pada Diri Sendiri. Bagi sebagian kita yang tidak menderita alexythymia, tidak tahu hal pun di dunia ini yang bersifat alamiah daripada memiliki suatu emosi dan mengetahui apakah sebenarnya ini. Kita semua dapat mengingatnya beberapa kali ketika suasana hati ( $m o o d)$ kita sangat kuat (kelahiran seorang anak) atau sangat jernih (memperoleh keberhasilan yang tidak diharapharapkan) sehingga kita sama sekali tidak memiliki kesulitan dalam semua hal dalam mengenali semua itu.

Lebih dari sekedar menciptakan respon-respon emosi yang agak ringan, situasi-situasi lain memancing bukan saja suatu respon tunggal yang secara jelas diberikan label, tetapi suatu campuran 
perasaan yang kompleks. Dalam kasus lain, tugas untuk mengidentifikasi perasaan kita sebenarnya secara benar bisa jadi sulit, dan beberapa orang cenderung secara lebih baik untuk melakukannya daripada orang lain (Stein, 2010). Mengapa suatu kemampuan untuk mengenal keadaan emosi kita adalah berguna, banyak alasan yang mungkin dan inilah alasan yang paling pokok yaitu: emosi memberi kita informasi mengenai penilaian kita. Alasan pertama didasarkan pada suatu argumentasi bahwa emosi merupakan suatu jenis informasi, karena emosi secara jelas memberi tahu kita bagaimana mengevaluasi sesuatu-orang, hal-hal, situasi, gagasan-suatu pemahaman yang akurat atas emosi kita artinya bahwa kita memiliki informasi yang lebih akurat mengenai evaluasi-evaluasi.

Emosi sebagai Kata Kunci untuk Bersikap. Dengan memiliki informasi mengenai penilaian-penilaian terhadap diri sendiri maka memberikan kita kata-kata kunci yang penting mengenai cara-cara yang lazim untuk berperilaku dalam berbagai situasi yang ada. Banyak emosi merupakan sinyal bagi kita mengenai dimana kita harus mengarahkan energi, jika kita tidak mengidentifikasi secara akurat emosi tersebut maka kita tidak akan dapat bertindak dengan cara yang paling layak (Stein, 2010). Menurut Hanafi (2010) performance perilaku auditor dipengaruhi oleh kecerdasan emosional dan spritual, didukung juga oleh Hidayat (2012) bahwa didalam nya terdapat locus of control yang mempengaruhi seseorang untuk bertindak dan berhubungan dengan sesama. Yuresta (2011) melihat adanya faktor-faktor yaitu motivasi, stress, reward dan rekan kerja yang mempengaruhi kinerja seorang akuntan, bagaimana rekan kerja bersikap mencerminkan kondisi sebuah budaya dalam organisasi.

Perasaan tidak enak merupakan suatu sinyal dimana sesuatu pelanggaran telah terjadi dan sinyal tersebut memacu untuk mengarahkan perhatian dan upaya ke arah memperbaiki kerusakan tersebut. Suatu kegagalan untuk mengenali secara akurat dan memberikan label perasaanperasaan ini bisa jadi menghasilkan karya penting untuk dilakukan. Selama stress dan gejolak yang tinggi, mereka yang memiliki pengenalan lebih jelas mengenai keadaan emosi mereka secara aktual menunjukkan hal yang lebih baik. Pada saat pertama kali terlihat kesulitan kecil untuk berbicara mengenali kesultankesulitan dalam mengenali keadaan emosi diri kita sendiri, tidak kelihatan sama sekali keanehan untuk berbicara mengenai kesulitan-kesulitan dalam mengidentifikasi emosi orang lain. Orang lain sangat sulit "membaca", seringkali pada saat kita paling ingin untuk dapat membaca mereka. Kesulitan-kesulitan dalam memahami apa yang "sebenarnya" dialami seseorang yang menyedihkan bagi semua orang norman.

Budaya Kerja. Menurut Schein dalam Ivancevich (2006) menjelaskan model organisasi tiga lapis Schein bahwa terdapat beberapa atribut budaya yaitu :

1. Dokumen : Hal ini berkaitan dengan dokumentasi data-data perusahaan yang tertata rapi dan terstruktur dari waktu ke waktu, dengan tujuan semua aktifitas perusahaan atau organisasi dijadikan acuan ataupu pedoman dimasa depan.

2. Desain fisik : Bentuk yang dapat dilihat secara jelas tentang desain organisasi memudahkan manajemen untuk mengambil keputusan dan mendistribusikan keputusan tersebut

3. Kerapihan : Unsur ini tidak bisa dipisahkan dari organisasi jika ingin tumbuh dan terus berkembang, karena akan memudahkan untuk mencari data dan segala hal yang berhubungan dengan perusahaan. Semua tersusun sesuai dengan divisi dan satuan tugas pelaksana dalam setiap kegiatan.

4. Bahasa : Penggunana bahasa dalam komunikasi disebuah organisasi memegang peranan yang sangat penting, dengan adanya standar bahasa yang digunakan bertujuan 
untuk menghindarkan perbedaan persepsi didalam organisasi.

5. Jargon : Setiap perusahaan memiliki semboyan untuk membangkitkan semangat dan motivasi karyawana dalam bekerja, bahkan hal ini dijadikan pembeda dengan perusahaan ataupun organisasi yang sejenis.

6. Etos dan praktik kerja : Partisipasi kerja menjadi penting untuk melihat pencapaian sebuah organisasi, tingginya semangat dan aktifitas kerja merupakan salah satu indikasi seorang karyawan merasa nyaman berada dalam sebuh organisasi.

7. Hari kerja yang adil untuk pembayaran yang adil : Setiap individu dalam organisasi memiliki kemampuan dan kapasitas yang berbeda, sehingga mereka tidak bisa diberikan pembayaran yang sama. Bahkan mereka yang bekerja over time juga harus diberikan kompensasi yang sebanding dengan jam kerja yang dilakukan.

8. Kesetiaan : Seorang individu bertahan dalam waktu yang cukup lama bahkan hingga pensiun menunjukan kesetian yang tinggi kepada perusahaan.

9. Komitmen : Menjaga rahasia perusahaan adalah sebuah kewajiban bagi setiap individu yang berada dalam sebuah organisasi ataupun perusahaan, yang senantiasa dilengkapi dengan perjanjian tertulis.

10. Membantu orang lain : Setiap perusahaan memiliki divisi dan bagian yang memiliki tugas dan fungsi yang telah ditetapkan dalam job description, tetapi hal itu tidak membatasi mereka untuk membantu antar sesama bagian ataupun dalam satu bagian atau divisi yang sama.

11. Kinerja membuahkan penghargaan : Reward and punisment selalu berjalan lurus, hal ini menandakan perusahaan menghargai individu-individu yang memberikan kontribusi lebih dibanding yang lain, penghargaan (reward) bisa dalam bentuk materi dan non materi.
12. Ekuitas manajemen : Kepemilikan manajemen juga menentukan perjalanan sebuah organisasi, jika keputusan direksi tidak disetujui oleh pemilik (owner) perusahaan maka tidak akan tercapai tujuan yang telah ditetapkan.

13. Kompetensi : Setiap individu didalam organisasi atau perusahaan memiliki kompetensi yang berbeda dan hal ini dibutuhkan perusahaan untuk tampil dan bersaing dengan para kompetitor, semakin banyak individu yang memiliki kompetensi (skill) spesial seperti ahli pajak, ahli strategi, ahli psikologi, ahli keuangan dan lainnya maka akan memudahkan dalam persaingan bisnis.

Moghadas (2013) mengatakan bahwa keterkaitan moral dipengaruhi oleh kecerdasan spritul seseorang, dimana moral merupakan bagian dari budaya. Membedakan budaya yang kuat dan yang lemah sering berguna, budaya yang kuat dicirikan oleh adanya karyawan yang memiliki nilai inti bersama. Semakin banyak karyawan yang berbagi dan menerima nilai inti, semakin kuat budaya dan semakin besar pengaruhnya terhadap perilaku. Organisasi keagaaman, sekte dan beberapa perusahaan Jepang seperti Toyota, merupakan contoh organisasi yang memiliki budaya kuat dan berpengaruh.

Mempertahankan budaya. Sosialisasi adalah proses dimana perusahaan memperkenalkan karyawan baru pada budaya perusahaan. Proses sosialisasi perusahaan terus berlangsung sepanjang karir seorang individu. ketika kebutuhan organisasi berubah seperti, karyawannya harus beradaptasi dengan kebutuhan tersebut, ini berarti bahwa kebutuhan baru tersebut harus disosialisasikan. Tetapi ketika kita mengakui bahwa sosialisasi itu ada, kita juga harus mengakui bahwa hal tersebut lebih penting pada beberapa waktu dibandingkan dengan pada waktu lainnya. 
Orang yang ber-EQ tinggi akan berupaya menciptakan keseimbangan dalam dirinya; bisa mengusahakan kebahagian dari dalam dirinya sendiri dan bisa mengubah sesuatu yang buruk menjadi sesuatu yang positif dan bermanfaat. Agustian (2006) menyatakan bahwa EQ merupakan kemampuan untuk merasa, dan kunci kecerdasan emosi adalah pada kejujuran suara hati, dan suara hati itulah yang harus dijadikan pusat prinsip yang mampu memberi rasa aman, pedoman kekuatan serta kebijaksanaan.

EQ menentukan potensi seseorang untuk mempelajari keterampilanketerampilan praktis yang didasarkan pada kelima unsurnya. Sedangkan kecakapan emosi menunjukkan seberapa banyak potensi itu yang telah dipelajari, dimiliki, dan diterapkan dalam kehidupan seharihari. Memiliki IQ yang tinggi tidak menjamin seseorang memiliki kecakapan emosi. Namun ia hanya mempunyai potensi maksimum untuk mempelajarinya. Sehingga seseorang ber-EQ tinggi mampu mengambil sikap yang lebih objektif dalam kehidupannya.

Seorang pekerja yang memiliki EQ yang stabil dan tinggi berarti mereka dapat mengelola emosi mereka dengan baik. Dengan begitu mereka akan lebih memiliki pertimbangan yang komprehensif dalam bersikap dan berhubungan dengan orang lain. Setiap perkataan dan tingkah laku yang akan dia lakukan tentu akan dipertimbangkan agar tidak menyinggung orang-orang disekitar.

\section{METODE}

Jenis penelitian digunakan adalah penelitian survey. Populasi dalam penelitian ini adalah karyawan Bumida di Cabang Pekanbaru, Dumai dan Padang, semua dijadikan sampel sebanyak lebih kurang 60 (enam puluh orang), baik sebagai karyawan tetap maupun yang berstatus mitra kerja. Penelitian ini menggunakan metode deskriptif, untuk melihat pengaruh kecerdasan emosional karyawa terhadap budaya kerja. Pengumpulan data menggunakan metode penyebaran kuisioner dan wawancara dengan beberapa karyawan. Selanjutnya teknik analisa data menggunakan uji validitas, uji reliabilitas dengan menggunakan nilai cronbach alpha. Juga menggunakan uji regresi sederhana untuk menguji hipotesis ini.

\section{HASIL}

Untuk melihat adanya pengaruh kecerdasan emosional dan kecerdasan spritual terhadap budaya kerja pekerja di PT. Asuransi Bumiputera Muda 1967 (BUMIDA), penulis menyebarkan kuesioner kepada karyawan BUMIDA yang berada di Kantor Pekanbaru, Dumai dan Padang. Untuk memudahkan pengumpulan data kuesioner diberikan langsung kepada responden, begitupula dengan tata cara pengumpulan kuesioner dikumpulkan langsung dari responden. Kuesioner yang disebarkan sebanyak 60 kuesioner dengan tingkat pengembalian sebanyak 55 kuesioner dan diambil 55 kuesioner untuk penelitian, sedangkan 5 kuisioner tidak diisi karena karyawan tersebut sedang dinas keluar kantor.

Sebelum dilakukan pengujian hipotesis, maka instrumen masing-masing variabel penelitian dilakukan uji validitas. Untuk mengetahui tentang valid atau tidaknya item-item pertanyaan dalam kuesioner dapat dilihat dari angka corrected item total correlasi. Angka korelasi ( $\mathrm{r}-$ hitung) yang diperoleh kemudian dibandingkan dengan angka kritis pada tabel korelasi product moment (r-tabel). Apabila r-hitung lebih besar daripada rtabel (r-hitung > r-tabel), maka item pertanyaan dianggap valid. Berdasarkan tabel $\mathrm{r}$ product moment, dengan jumlah data sebanyak 55 dan tingkat kepercayaan sebesar 95\% maka dapat diperoleh nilai rtabel sebesar 0,195 $\left(\mathrm{r}_{\text {kritis }}=0,220\right)$.

Uji validitas mengukur sejauh mana pertanyaan-pertanyaan dalam kuesioner dapat mengukur apa yang sebenarnya ingin diukur, analisis ini dilakukan dengan menggunakan faktor analisis. Untuk menilai kehandalan dari item-item

p.ISSN: $2407-800 X \quad$ e.ISSN: 2541-4356 
pertanyaan yang akurat apabila digunakan pada tempat dan waktu yang berbeda maka dilakukanlah uji reliabilitas. Nilai $r$ tabel untuk 55 responden $(n-2=55-2=53)$ yaitu 0,224 Sebuah item dinyatakan handal apabila menghasilkan nilai cronbach alpha > 0,224. Berdasarkan hasil uji maka nilai cronbach alpha $>0,224$. Apabila dibawah 0,224 maka dianggap kurang baik (Priyatno, 2010). Berdasarkan hasil pengujian reliabilitas yang telah dilakukan, diperoleh hasil seperti yang terlihat pada Tabel 1 berikut :

Tabel 1. Hasil Uji Reliabilitas Kecerdasan Emosional

\begin{tabular}{|l|l|l|l|}
\hline Variabel & $\begin{array}{l}\text { Cronbach's } \\
\text { Alpha if Item } \\
\text { Deleted }\end{array}$ & $\begin{array}{l}\text { Batas } \\
\text { Toleransi }\end{array}$ & Keterangan \\
\hline $\begin{array}{l}\text { Mengenali } \\
\text { diri sendiri }\end{array}$ & 0,347 & 0,224 & Reliabel \\
\hline $\begin{array}{l}\text { Mengelola } \\
\text { emosi }\end{array}$ & 0,565 & 0,224 & Reliabel \\
\hline $\begin{array}{l}\text { Memotivasi } \\
\text { diri sendiri }\end{array}$ & 0,672 & 0,224 & Reliabel \\
\hline $\begin{array}{l}\text { Mengenali } \\
\text { emosi orang } \\
\text { lain }\end{array}$ & 0,465 & 0,224 & Reliabel \\
\hline $\begin{array}{l}\text { Membina } \\
\text { hubungan }\end{array}$ & 0,583 & 0,224 & Reliabel \\
\hline
\end{tabular}

Berdasarkan data pada Tabel 2 diketahui bahwa hasil uji reliabilitas untuk variabel kecerdasan emosional memililiki nilai cronbach alpha > 0,224 untuk setiap dimensi/indikator. Ini menujukkan bahwa uji reliabilitas untuk variabel kecerdasan emosional adalah reliabel.

Tabel 2. Hasil Uji Reliabilitas Budaya Kerja

\begin{tabular}{|l|l|l|l|}
\hline Variabel & $\begin{array}{l}\text { Cronbach's } \\
\text { Alpha if } \\
\text { Item } \\
\text { Deleted }\end{array}$ & $\begin{array}{l}\text { Batas } \\
\text { Toleransi }\end{array}$ & Keterangan \\
\hline Bahasa & 0,331 & 0,224 & Reliabel \\
\hline Kerapihan & 0,613 & 0,224 & Reliabel \\
\hline Kesetiaan & 0,348 & 0,224 & Reliabel \\
\hline $\begin{array}{l}\text { Etos dan } \\
\text { Praktik } \\
\text { Kerja }\end{array}$ & 0,193 & 0,224 & Reliabel \\
\hline $\begin{array}{l}\text { Jargon } \\
\text { atau } \\
\text { Budaya }\end{array}$ & 0,529 & 0,224 & Reliabel \\
\hline $\begin{array}{l}\text { Membantu } \\
\text { Orang } \\
\text { Lain }\end{array}$ & 0,444 & 0,224 & Reliabel \\
\hline
\end{tabular}

Berdasarkan data pada Tabel 2 diketahui bahwa hasil uji reliabilitas untuk variabel budaya kerja memililiki nilai cronbach alpha
$>0,224$ untuk setiap dimensi/indikator. Ini menujukkan bahwa uji reliabilitas untuk variabel budaya kerja adalah reliabel.

Tabel 3. Uji Regresi

\begin{tabular}{|c|c|c|c|c|c|c|}
\hline \multicolumn{7}{|c|}{ Coefficients $^{\mathrm{a}}$} \\
\hline \multirow{2}{*}{\multicolumn{2}{|c|}{ Model }} & \multicolumn{2}{|c|}{$\begin{array}{l}\text { Unstandardiz } \\
\text { ed } \\
\text { Coefficients }\end{array}$} & \multirow{2}{*}{$\begin{array}{l}\text { Standardi } \\
\text { zed } \\
\text { Coefficie } \\
\text { nts } \\
\text { Beta }\end{array}$} & \multirow[b]{2}{*}{$\mathrm{T}$} & \multirow[b]{2}{*}{ Sig. } \\
\hline & & B & \begin{tabular}{|l|} 
Std. \\
Error
\end{tabular} & & & \\
\hline \multirow[t]{2}{*}{1} & (Constant) & 40.405 & 5.724 & & 7.059 & .000 \\
\hline & EMOSIONAL & .104 & .099 & .143 & 1.048 & .299 \\
\hline & $\begin{array}{l}\text { Dependent V } \\
\text { DAYA }\end{array}$ & ariable: & & & & \\
\hline
\end{tabular}

Pada uji regresi didapat bahwa nilai Beta 0.143 (positif) yang artinya terdapat pengaruh positif antara kecerdasan emosional dengan budaya kerja, jika dilihat dari nilai sig 0,299 yang lebih besar dari 0,050 berarti pengaruhnya tidak signifikan. Sebuah hasil penelitian jika sampel kurang dari 100 maka kecenderungannya memang tidak signifikan (Sholihin dan Dwi Ratmono, 2013).

\section{PEMBAHASAN}

Kecerdasan emosional yang meliputi mengenali diri sendiri, mengelola emosi, memotivasi diri sendiri, mengenali emosi orang lain dan membina hubungan sangat memberikan dampak pada budaya kerja didalam sebuah perusahaan. Jika seorang karyawan sudah mengenali dirinya sendiri yang artinya tau kekurangan dan kelebihan serta karakternya pribadi akan muda untuk menyesuaikan dengan rekanrekan kerja.

Hal ini tentunya berimbas juga ketika sudah mengenali diri sendiri maka akan mampu mengelola emosi agar tidak terjadi pertikaian antara sesama pekerja, disisi lain seorang karyawan mampu menjadi motivator untuk dirinya sendiri dan menghindari sifat moody atau terkadang baik terkadang jahat. Seorang karyawan yang sudah mampu menjadi motivator untuk dirinya sendiri juga mampu mengenali emosi orang lain, kapan waktunya dia berbicara serius dan santai dengan rekan kerja karena melihat situasi 
emosional rekan kerja. Widayat (2016) menyatakan bahwa kecerdasan emosional juga mempengaruhi sikap etis soerang pekerja, maka dari itu jika hal ini mampu terpelihara maka hubungan sesama karyawan akan menjadi harmonis dan meminimalisir perselisihan antar karyawan.

Memiliki kecerdasan emosional pada taraf tinggi ternyata sangat berguna dalam lingkungan kerja. Orang-orang dengan tingkat kecerdasan emosional yang tinggi akan lebih mudah peka dan respect dengan orang-orang disekitar, ia mengetahui dan memahami kesulitan dan kesusahan yang dihadapi oleh oran lain. Dengan demikian karyawan yang memiliki EQ yang tinggi akan disukai oleh customer karena selalu menjadi pendengar dan mencarikan solusi terhadap permasalahan yang dihadapi. Pada akhirnya image perusahaan akan positif dimata customer karena karyawan yang ada didalamnya mampu menampilkan dan memperlihatkan profesionalisme ketika menghadapi kesulitan yang beraneka ragam.

Aspek budaya kerja meliputi bahasa, kerapihan, kesetiaan, Etos dan Praktik Kerja, Jargon atau Budaya dan Membantu Orang Lain. Hal ini didukung oleh Wilson (2008) bahwa dalam hal etos dan praktik kerja dibutuhkan sisi emosional untuk menciptakan perilaku yang baik selama bekerja. Jika kualitas individu dalam sebuah organisasi sudah mumpuni maka kualitas budaya didalam organisasi akan cenderung lebih baik (Ali, 2008)

Kematangan dan ketenangan sisi emosional menjadi dasar membangun budaya kerja yang positif. Ketika budaya kerja sudah baik dan positif secara tidak langsung akan berimbas pada kepuasan kerja, sebagaimana Ariyanto (2005) menyatakan bahwa budaya kerja mempengaruhi kepuasan kerja didalam perusahaan, serta Tischler (2002) bahwa spiritualitas berhubungan dengan kinerja di tempat kerja atau efektivitas. Maka selanjutnya penelitian kombinasi antara kecerdasan emosional dan kecerdasan spritual dalam mempengaruhi budaya kerja.

Hipotesis yang menyatakan bahwa kecerdasan emosional berpengaruh positif

Jurnal Daya Saing tetapi tidak signifikan terhadap budaya kerja karyawan di Bumida Cabang Pekanbaru, Dumai dan Padang. Disini tidak signifikan disebabkan karena sampel yang kurang dari 100 orang (Sholihin dan Dwi Ratmono, 2013). Sehingga bisa dikatakan bahwa kecerdasan emosional memiliki pengaruh terhadap budaya kerja didalam perusahaan, sebagaimana menurut teori Goleman (2006) mendefinisikan EQ adalah kemampuan mengenali perasaan diri sendiri, serta mengelola emosi dengan baik pada diri sendiri dan dalam hubungan dengan orang lain. Tingkat emosional yang stabil akan mendukung seorang karyawan untuk bersikap lebih bijak dalam menghadapi berbagai karakter manusia terutama dalam dunia bisnis asuransi yang notabenenya memberikan layanan/service kepada pelanggan.

Selain itu beberapa penelitian yang pernah dilakukan bahwa kecerdasan emosional bukan hanya mempengaruhi budaya kerja tetapi banyak hal lainnya, seperti penelitian oleh Gupta (2014) bahwa kecerdasan emosional dipengaruhi oleh kemampuan berkomunikasi terutama dalam lingkup global. Yesil (2012) dalam penelitiannya menyampaikan bahwa budaya kerja berkaitan dengan inovasi yang dilakukan sebuah organisasi, selain itu Ali (2012) dalam penelitiannya menyebutkan bahwa budaya kerja berkorelasi dengan kinerja tenaga kerja. Vyas (2015) juga menyebutkan bahwa kecerdasan emosional seorang pemimpin akan menentukan kinerja para staff. Harrison (2016) menyebutkan bahwa kecerdasan emosional menentukan kesuksesan siswa yang mengambil program doktor. Abdillah (2017) menyatakan bahwa kecerdasan emosional memberikan dampak pada kinerja karyawan.

\section{SIMPULAN}

Kesimpulan yang diambil antara lain menunjukkan bahwa seorang yang memiliki kematangan dari sisi emosional akan mampu mengontrol diri dalam pekerjaan sehari-hari, baik kepada sesama karyawan maupun nasabah. Kecerdasan

p.ISSN: 2407-800X e.ISSN: 2541-4356 
emosional sangat dibutuhkan untuk menjaga suasana hubungan antar individu yang harmonis sehingga secara organisasi akan tertanam budaya saling membantu, tutur bahasa yang sopan, kerapihan dalam bekerja, kesetiaan terhadap perusahaan dan etos kerja yang baik.

\section{DAFTAR RUJUKAN}

Abdillah, MR. Adi Rahmat. 2017. Kecerdasan Emosional dan Dampaknya Terhadap Stress Kerja dan Kinerja Karyawan. Jurnal Ekonomi dan Bisnis Islam Vol. 2 No. 1 Juni 2017 ISSN 2528-4266 EISSN 2528-4274 Hal 43-57.

Ali., Hairuddin Mohd. Mohammed Borhandden Musah. 2012. Investigation of Malaysian Higher Education Quality Culture and Workforce Performance. Quality Assurance in Education Vol. 20 issue 3 pp 289-309 ISSN 09684883.

Ariyanto, Agus. 2005. Pengaruh budaya organisasi islami dan kepemimpinan spritual terhadap kepuasan kerja karyawan $M Q \quad$ Corporation Bandung. Jurnal Ilmiah Manajemen Muhammadiyah AcehVol. 2 No.1.

Bradberry, Travis \& Jead Greaves. 2007. Penerapan EQ ditempat kerja dan ruang keluarga. Think. Jakarta

Gupta, Shiv K., Teja Jadhav. 2014 Global Communication Skills and Its Relathionship with Emotional Intelligence. American Journal of Management Vol. 14 (4) 2014.

Goleman, D, 2006. Emotional Intelligence. Cetakan Keenam belas. Diterjemahkan oleh T. Hermaya . PT Gramedia Pustaka Utama, Jakarta.
Hanafi, Rustam. Spiritual Intelligence, Emotional Intelligence and Auditor's Performance. Jurnal Akuntansi \& Auditing Indonesia 14.1 (2010).

Harrison, Glen A. 2016. An investigation of the influence of emotional intelligence on Successful doctoral students in an online program at one University. A Dissertation Presented to The Faculty of the College Graduate Studies of Doctor of Education in Educational Leadership Lamar University.

Hidayat, W. (2012). ESQ dan Locus of Control sebagai Anteseden Hubungan Kinerja Pegawai dan Penerimaan Perilaku Disfungsional Audit pada Badan Pengawas Daerah (BAWASDA) Jawa Timur. Dalam Jurnal Mitra Ekonomi dan Manajemen Bisnis, 3(1), 50-74.

Ivancevich, John M, 2006. Perilaku dan Manajemen Organisasi. Jilid satu, Edisi Ketujuh. Erlangga. Jakarta.

Moghadas, Maedeh. Investigate of Relationship Between Moral Intelligence and Distress Tolerance in Isfahan Staff. International Journal 2.2 (2013): 2307-227X.

Sholihin., Mahfus. Dwi Ratmono. 2013. Analisis SEM-PLS dengan WarPLS 3.0 Untuk Hubungan Nonlinier dalam Penelitian Sosial dan Bisnis. CV Andi Offset. Yogyakarta.

Tikollah, M. Ridwan, dkk. 2006. Pengaruh IQ, EQ, SQ Terhadap Sikap Etis Mahasiswa Akuntansi. Simposium Nasional Akuntansi: Padang. 
Tischler, len., Jerry Biberman, Robert Mckeage. 2002. Linking emotional intelligence, spirituality and workplace performance: Definitions, models and ideas for research. Journal of Managerial Psychology Vol 17 issue 3 pp 203218 ISSN 02683946.

Vyas, Ekta. 2015. Intelligence and staff work engagement during Transformational change: a correlational study. A Dissertation Presented in Partial Fulfillment Of the Requirements for the Degree Doctor of Philosophy Capella University.

Widayat, Prama. 2016. Pengaruh kecerdasan emosional dan kecerdasan spritual terhadap sikap etis pekerja pada PT. Asuransi Bumiputera Muda 1967 Cabang Jakarta. Jurnal Daya Saing Vol. 2 No. 1 Februari 2016 PISSN 2407-800K E ISSN 25414356.

Wilson, Malino. (2008). Hubungan Kecerdasan Emosional dan Laku Warga Organisasi dengan Kinerja (Doctoral dissertation, Tesis, UGM, Yogyakarta).
Yesil, Salih., Ahmet Kaya. The role of organisational culture on innovation capability : an empiral study. International Journal of Information Technology and Business Management 29 Oktober 2012 Vol. 6 No. 1.

Yuresta, D., \& Taufikur Rahman, S. E. (2011). Analisis Pengaruh Motivasi, Stres, Reward dan Rekan Kerja terhadap Kinerja auditor di Kantor Akuntan Publik (Doctoral dissertation, Universitas Gadjah Mada). 